\title{
Deployed fears and suspended solidarity along the migratory route in Europe
}

\section{Introduction}

The paper departs from the moment in early 2015 when people coming north on the Balkan route reached the Hungarian-Serbian border and strives to reconstruct how the social discourses in a border village developed. The latter involved imbuing the undefined foreigners with threatening and dehumanizing meanings and suspension of the primary reactions, which included compassion and suspicion to the same extent. Two dimensions of the discourses that developed are distinguished: one in everyday talk, and the other in public speech involving both politics and media.

In the analysis, three interlinked perspectives are applied: a discursive approach which strives to follow the genesis of a discourse involving threats caused by migration that involved suspending compassion and dehumanizing migrants; an institutionalist approach applied to understand the interactions of the local, national, and transnational agents that contributed to the development of the hegemony of fear; and, finally, a structural approach that explains the background of social anxieties and how these were manipulated by discourses of fear and security.

The argumentation will be developed in five sections. The first presents the methods and the field of the empirical investigation: a Hungarian border village situated on the Balkan migratory route. The second introduces the conceptual and political framework which helps with understanding both the social background as well as the discursive realization of a politics of fear and security. This is continued in the third part by a presentation of how the politics of fear and security initiated by the local far-right in interaction with national and international actors was built up in Ásotthalom. The fourth section employs a structuralist approach to 
understand how the responsiveness to securitization can be explained by the social anxieties of the locals. The fifth part includes ethnographic verification and illustrates the previous sections by investigating discourse-based ethnographic encounters to show how curiosity, compassion, and solidarity were suspended and dehumanizing discourses became embedded in everyday talk. Thus, although the Hungarian border village is at the centre of our ethnographic examination, it should not be taken as an isolated entity: interactions between local, national, and transnational agents and structures should be considered in combination to understand how the border spectacle and dehumanization of migrants are connected to a more general delegitimization of transnational solidarity that supports the renewal of national border regimes.

\section{Research methods and field}

In recent years, a significant number of individuals and institutions have offered donations and engaged in volunteer work for refugees in Hungary, as in other countries on the European migratory route. Scholars have proven that the motivation for such acts of solidarity is also very similar; moreover, that these acts of solidarity entailed a process of increasing public awareness and responsibility (Feischmidt and Zakariás 2019). Nevertheless, the Hungarian public has been less influenced by solidarity than by security concerns. The international and the national media coverage of Hungary during the so-called refugee crisis of 2015 was also more focused on securitizing discourses and their role in propping up an authoritarian regime in Europe. However, we know very little about the socio-political circumstances and the concrete modalities concerning how the discourses of fear and the migration menace developed and spread throughout society.

The aim of my research is to address this gap: to help understand the dynamics - the creation, perpetuation, and alteration - of xenophobia and solidarity in a local context which was deeply affected both by migration and far-right politics. Initially, two settlements, each 
located on a different side of the Serbian-Hungarian border were the focus of inquiry. This paper discusses only the case of the Hungarian village of Ásotthalom. Nevertheless, at some points I make comparisons involving data from the Serbian village (Szerbhorváth 2016).

The research adopted an ethnographic approach and was effectuated through seven field visits that took place between July 2015 and December 2017. During these visits - the length of which varied between four and ten days - I took part in public events such as Sunday masses,

cultural festivals and commemorations, communal meetings, and observed everyday communication acts. I conducted interviews with local councillors, current and former mayors, the heads of local public institutions (kindergartens, schools, cultural centres, etc.), leaders and members of local ethno-cultural associations, owners, managers and employees at three agricultural companies which are the most important employers in the village, the priest and the lay leader of the local Catholic church, members of choir and the rosary group, the leader of the only oppositional party, the local doctor, owners and employees of the two local pubs, and one professional and two volunteer border guards. I made repeated visits to two families living in the close vicinity of the border. All interviews were transcribed and analyzed together with the notes taken during the fieldwork. The ethnographic fieldwork was supplemented by online ethnography of the public Facebook activity of the main actors and the national as well as international media coverage of the village.

\section{Politics of fear and discourses of threat: conceptual approaches}

Civic forms of solidarity with refugees during the long summer of migration and its aftermath can be understood (and are understood by the editors and authors of the current special issue) as reactions to a crisis of institutional forms of solidarity (Schwiertz and Schwenken 2020) that culminated in the "organized non-responsibility" of most EU Member States in 2015 (Pries 2019, 3). Earlier studies have drawn attention to the challenges that solidarity - originally, 
mostly framed by national institutions and perceptions - was exposed to because of the increase in ethnic and cultural diversity (Oosterlynk et al. 2015; Bauböck and Scholten 2016). This paper adds to this another form of challenging diversification related to the political inclusion of underprivileged regions whose populations, because of their own disenfranchisement and different historical trajectories, have hesitate to join the community of the responsible. Hesitation and ambivalent reactions have represented fertile soil in which political alternatives could take root, restricting responsibilities to the national level and suspending moral and political obligations towards those not belonging to the latter. This may be understood as a renationalization of solidarity from below. Nevertheless, as this paper will argue, this process does not involve a legitimate form of solidarity but rather concerns the elimination of solidarity as justified both by long-term dispossession and newly arising threats deployed by politicians who promise security and the solidification of physical borders and mental boundaries.

Scholars of the radical- and far-right recognized long ago the significance of discourses that react to and perpetuate social threats and feelings of insecurity. Securitization, as the constructivist approach in security studies has defined it (Buzan, Wæver, and de Wilde 1998; Huymans 2006), involves the discursive construction of threats as essential to the formation, expansion, and reinforcement of power and control legitimized in terms of protection. Securitization is a form of governance that - as Fassin claims - links the construction of (state) borders to the production of (social) boundaries (Fassin 2011). In many countries security-led governance has emerged in parallel with the discourse about the "crisis of migration" or "crisis of multiculturalism," and is tightly connected to the rise of the far-right. As Ruth Wodak has observed, the so-called normalization or mainstreaming of the far-right also primarily uses fear (Wodak 2015). Moreover, as one analysis of the scenarios of danger presented in US media concluded, "fear has become a dominant public perspective. Fear begins with things we fear, 
but over time, with enough repetition and expended use, it becomes a way of looking at life, (...) a framework for developing identities and for engaging in social life" (Altheide 2002, 3).

A central element of the politics of fear is the designation of individuals or groups of individuals as the enemy. This is effectuated by discourses that depict members of a social category - usually some kind of ethnic, religious, or political minority - as enemies, who, in the course of such process of enmification, are dispossessed of their human dignity. There are two modes of degradation: one is racism, which considers the enemy to take a human form, albeit of a different and usually inferior race; the other is dehumanization, which identifies the enemy as belonging to the world of animals and, more specifically, to dangerous ones. Following the 9/11 terrorist attacks, a dehumanizing discourse developed that specified Muslims as the enemy and embodied the related danger in media accounts that sought to legitimize the Bush administration's foreign policy goals. In Europe, the Danish MP Pia Kjorsgaards identified Muslims as a "cancer" that was threatening Denmark (Steuter and Wills $2010,55)$. Sometimes the animals that are metaphorically evoked in the process of enmification are fearsome, while others are revolting and prolific, but their main feature is always their inferiority. The destruction of an enemy that is identified with an animal is not just a possibility, but an act that can be thoroughly justified in moral terms. If the enemy represents a disease, exterminating it is a responsible and logical reaction undertaken on behalf of other "humans".

Dehumanizing discourses are currently growing in legitimacy due to their appearance in politics at the governmental level. Michal Buchowski writes about the mainstreamed forms of Islamophobia in Poland: In a parliamentary speech in 2015, shortly before the elections, Jaroslaw Kaczynski warned that potential migrants posed a biological threat to Europe: 'There are cases of diseases that have not been witnessed in Europe for long [for a long time], cholera on [a] Greek island, dysentery in Vienna, different parasites, protozoa' (Buchowski 2017, 521). Buchowski continues by commenting that Muslim immigrants pose no credible threat to the 
Polish economy or "culture" and concludes exactly what this paper also proposes: "...fear is generated discursively."

In Hungary, the discourse on security was instituted by a speech of Prime Minister Viktor Orbán about illiberal democracy that introduced at the same time the term "crisis." Orbán claimed that the crises of the Western world are rooted in multiculturalism and permissive policies with regard to migration (Szalai and Göbl 2015). After sporadic comments by the government, the first coordinated form of action against immigration was the initiation of a referendum (a so-called "national consultation") about migration and terrorism. This was followed by a series of appeals to collective anxieties and the state of exception, which included a poster campaign and the physical enclosure of the state through the erection of a $175-\mathrm{km}$ long fence along the southern border of the country. Due to the border closure and the harsh treatment of refugees who became congested on state territory (which included criminalization, arrest, and show trials) there was a significant decrease in the number of asylum-seekers, followed by the nearly complete elimination of the infrastructure suitable for their supply and accommodation. In the spring of 2016, with almost no refugees on the territory of the state, the government initiated another campaign. The efficiency of this campaign may be indicated by

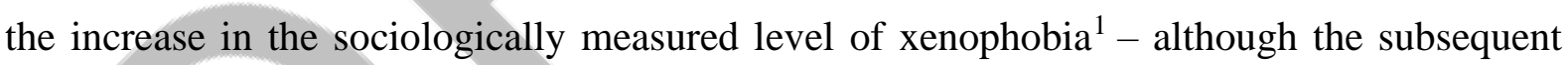
referendum ${ }^{2}$ on the EU's migrant quotas was invalidated due to the low turnout rate, representing a trend in attitudes that points in the opposite direction. By this time, nevertheless, the "migration crisis" or the focus on the "migrant threat" had become central to the political life of Hungary (Cantat and Rajaram 2018; Nagy 2018), leading up to the April 2018 general election campaign. Scholars (Bernáth and Messing 2016; Melegh 2017) have found strong evidence for the collapse of liberal-humanitarian narratives in Hungary and the development of a securitizing hegemony in comparison with the situation in other European countries. Based on comparative survey data, the extreme level of fear and the correlated high level of rejection 
of migrants has been explained (Messing and Ságvári 2018) by a lack of social cohesion and inclusion, as well as material deprivation and the absence of social trust in Hungary.

In what follows the relationship between the rise of a politics of fear and pre-existing social anxieties followed by the suspension of compassion and solidarity will remain the focus of analysis, but the topic will be examined from a different angle. Instead of looking at the structural factors affecting the politics of fear on a macro level, we monitor the construction of the hegemony of fear from a micro perspective, which a discourse-oriented ethnographic approach allows. In this regard, the paper follows in the steps of those anthropologists who have emphasized the significance of locality and observed the transformation that occurs in localities which are both physically and politically touched by international migration and a politics of fear practiced by far-right actors (Hann 2016, Feischmidt and Szombati 2016, Pasieka 2017, Thorleifson 2017) .

\section{The spectacle of border protection and the dehumanization of migrants in} Ásotthalom

Various sources indicate that the idea of the border fence that was built by the Hungarian state on the Hungarian-Serbian border was proposed by László Toroczkai, the mayor of Ásotthalom, who also confirmed this fact during our first interview. He acknowledged at the same time that the action taken by the Hungarian government 'is correct; moreover, these are historical acts at a historical moment, when the Schengen borders must be defended.' The main role in decision-making and the implementation of border control was occupied by state authorities, although some surveillance operations remained under the control of the municipal authority through the involvement of a local militia (polgárörség), as well as the so-called "field watchmen" (mezöor $)$, a service created by the mayor that made him popular among local residents, as well as among sympathizers from afar. 
During a village assembly in July 2015 which happened in the first days of my fieldwork and was attended by a majority of local residents, the mayor drew attention to threats concerning public sanitation. The representative of the competent authority made futile efforts at the meeting to reduce panic by emphasizing that no cases had been identified that indicated a cause for concern. Nevertheless, posters issued by the mayors' office appeared throughout the settlement showing the hand of a leprosy patient, and the scene of a medical intervention.

Because many local residents (but mainly elderly people and poor families) live in farmsteads that are relatively remote from the centre of the village, the mayor primarily built his communication strategy around their fears. Together with comments about a deteriorating sense of security, he argued that 'this illegal migration is killing the settlement' with regard to the technicalities of mobilization and the organization of defense. He further increased the visibility of the citizen guard and guardians of the fields - who patrolled in camouflage-colored uniforms - using a video distributed across social media. The yideo introduces the men and their assets, both appropriate for manhunts, in a style that bears a resemblance to and resonates with scenes familiar from Hollywood movies. In the video, the guardians of the fields and citizen guards are seen scanning the southern border from cars, horses, and motorbikes, while the village and its inhabitants are invisible. Indeed, the short, dynamic video quickly went viral on YouTube. In commentary published only one day after the online release of the video, Alfahír, one of the leading websites of the Hungarian extreme right, wrote the following: 'Toroczkai [the mayor] is receiving acknowledgement from all over Europe.' ${ }^{3}$ In less than one day following the release of the video it had been watched 150,000 times, which number rapidly increased, and the mayor claimed it had been viewed one-and-a-half million times in the interview that was undertaken in September 2015.

The video became internationally famous under the title 'anti-refugee movie,' although its international reception was marked by negative as well as positive reactions, both of which 
combined to make Toroczkai into an anti-refugee, action-man media star. Russia Today emphasized the mayor's activities in relation to the impact of wars and starvation, also connected to Toroczkai's earlier right-wing radicalism. From other parts of the Russian media the mayor received a particularly positive reaction. ${ }^{4}$ The British tabloid the Daily Mail, which has fostered its reputation in conjunction with Brexit, in spite of the subdued tone of the related article still provided space and opportunity for radical British right-wing readers to post appreciative comments about Toroczkai which are still available online. ${ }^{5}$ The New York Times published an article with the title "Has Europe reached the Breaking Point?" which analyzed the plight of the EU with an emphasis on uncertainties, and used the fence at the border as a symbol of European anxieties. Toroczkai ('a rising ultranationalist star of far-right European politics') is represented as a partly dramatic, partly absurd character. $^{6}$

Toroczkai's reputation increased most dramatically after his participation on a TV show with a popular American political commentator. Last Week Tonight with John Oliver on the $28^{\text {th }}$ September, 2015 covered the issue of migrants and refugees in Europe. ${ }^{7}$ In August 2016 the number of viewers of this show was estimated at nearly eight-and-a-half million. In this portrayal, Toroczkai is presented as a main actor in the industry of hatred. Nonetheless, John Oliver's approach to the case also made the Ásotthalom mayor a ridiculous, even absurd figure.

The most important pillar of political communication with regard to migrants in Ásotthalom is social media, as the mayor is in regular contact with his Facebook followers (their number exceeds 40,000). His communication is intense as he posts on an almost daily basis. In terms of this content regarding the settlement and his position as a mayor, the perennial topic of "migrants" is most common, whether the latter appear as sole items of interest or in connection with other subjects. To quote one of his "migrant-related" posts:

... Recently I woke up twice in the middle of the night to the yelling of invaders at the fence of our farmstead. On the picture you can see our 'catch of the week.' Our field guards report more and more often that from the other side of the border fence migrants are 
showing off their knives to guards, policemen and soldiers, and saying how they are going to cut off their heads. Then, if there are no guards, they immediately start cutting through the fence to rush towards the interior of the country. At the same time, we are now also many in number, and we capture and tie them up. The problem is that even if we stop them invading the country in an unchecked way by doing this, because of the insane laws, after fingerprinting and examination they are free to go after a couple of days. This is the responsibility of the legislators. So this problem is still far from being resolved, even if it threatens our world. (FB, 24. 04. 2016; Translated by the author)

In order to imbue this simple story with dramatic potential, a photo is added to the post which shows the mayor with his dog, while in the background we see a member of the citizen's guard in a victorious position and a group of young men who have been captured. Some of the comments below the post praise the beauty of the dog, similarly to the comments under previous posts that included reference to the mayor's pet. From comments about the dog's condition the discussion is channelled towards its feeding, from pet food to refugees, and then back to the dog that is fed only with "quality pet food." Between the commentators there is no debate. The peak of the series of comments involves talk of annihilation, followed by many additional emoticons (thumbs up, smilies, etc.). ('It's like tilting at windmills because even if you collect them, they will be strolling around again in a matter of a few hours or days. Boom in the head ... (-) PS.: The dog is nice! (-)"'). The edge of the verbal violence is softened by humor, creating a mixture of hatred and cynicism.

The de-legitimization of transnational solidarity and cultural diversity happens on the same social media sites that create a discourse about political enemies and place the national and international organizations that are dedicated to supporting the refugees within these frames. 'The real terror just arrived to Europe, as I previously indicated, but only a few have taken me seriously. All the responsibility is on those moaning and horrified politicians who have been forcing and also who today force multiculturalism upon Europe.' This statement, published firstly on Facebook, was repeated at the celebration of Independence Day in Warsaw 
in 2015 , where Torockai was one of the main speakers. ${ }^{8}$ Concerning issues of foreign policy and Hungary's relation to the European Union, his position and arguments are very similar to the ones used by the Hungarian government in the poster campaign of 2015 and in the October 2016 referendum campaign. Nevertheless, with his international communication campaign and presence the mayor of Ásotthalom has managed to create and maintain his own allegiance of far-right political actors in the region and position himself as one of the major figures.

As this section started, it also finishes: by pointing out the similarities between the local far-right position and the position of the Hungarian government concerning issues of migration. What gives the local far-right its legitimacy? A key factor is that Ásotthalom lies in the immediate vicinity of the state border where the border fence has been built. This is what the video shows, what the Facebook posts thematize, and what creates a border spectacle - as Rajaram and De Genova would call it; a term which scholars of migration have already applied to the European border regimes (Rajaram and Cantat 2018). The border spectacle represents the enactment of exclusion through the enforcement of a border which produces illegalized migration and illegal migrants (De Genova 2013). As we have seen, such spectacularization of borders produces two sets of roles: one of defenders presented as male heroes (Helms 2016), and another of aggressors presented as dehumanized enemies. How this border spectacle is produced in old and new (social) media has been shown in this section, while how it affects the everyday thinking and action of individuals is presented in a following section of this paper. Before this, the social and economic circumstances which determine the reactions of the affected individuals are described.

\section{Social anxieties and the demand for a politics of fear on the European peripheries}

The current mayor first entered the local political scene in 2013 as a young man with a personal affiliation to the settlement who was well known mainly from the radical-right. He won the 
off-year elections for the settlement in 2013, a feat which he managed to repeat a year later at the regular municipal elections with the backing of the local electoral base of the previously national-conservative currently rather far-right populist governing party, FIDESZ. The ensuing radicalization of political views was widespread, especially among active young and middleaged inhabitants. The elderly tended to overlook the radical past of the mayor; his 'social sensitivity' and 'commitment to the community' (as it was formulated in our conversations) were deemed more important. For these reasons, he also enjoyed the support of local elites. His support grew significantly during the refugee crisis both in the village and nationwide. In June 2016, Toroczkai was elected vice-president of the nationalistic and racist radical right-wing party Jobbik. However, after Jobbik significantly changed its position prior to the 2018 elections by shifting towards a conservative mainstream stance with leftist elements, the mayor of Ásotthalom created a new movement (Mi Hazánk/ Our Homeland) which appears to be occupying Jobbik's original far-right position, thereby handing the former party an advantage as it can now situate itself more easily in the middle of the political spectrum.

In order to understand the support of the far-right and the politics of fear from a local perspective, in what follows we sketch out the social and economic circumstances which shape the everyday lives of the villagers. Ásotthalom is situated in the southern part of Hungary close to the Serbian border, not far from the city of Szeged. Almost half of the village's permanent population is residing in the outer zone of scattered farmsteads (tanya), from where the infrastructural services of the inner zone are more difficult to access. The number of inhabitants residing in the outer zone is constantly growing due to the arrival of families, usually with many children, who, having fled the urban centers or post-industrial zones of the county, struggle to survive. Hence, the settlement had already been affected by migration before the refugee wave in 2015 , mainly because of socially induced internal migration, but also due to the emigration of locals as labor migrants to various western European countries. 
For half a century, local settlement dwellers secured their livelihoods through engaging in dual forms of employment in the industry of Szeged and other nearby settings, and in local agriculture. As the major employers disappeared and the demand for labor of the remaining firms decreased, most local residents were driven back to the land. However, the agricultural potential of the area is conditioned by the state of available land, which is difficult to cultivate, as well as the farmstead structure that can be made profitable only through a well-organized sales and marketing approach. During the last period of state-socialism, sales were made through state-owned companies, while cultivation took place in fields that were partly privately owned, and partly co-operative property. Following the post-socialist transition, co-operatives were created that could effectively sell the meat and vegetables their members produced to large shopping centers. However, this system had collapsed by the beginning of the 2000s. The immense storage units and cold stores that were constructed following the transition are now empty, and farmers are struggling to survive. In terms of sales, three medium-sized companies were left standing in Ásotthalom, but these pay very low wages, mainly on the basis of temporary employment.

Accordingly, the fluctuation of the workforce is high: many residents, especially youngsters, look for work abroad, and the smallholdings that pack and distribute agricultural products mainly employ seasonal workers, a significant proportion of whom are also from abroad, either from Romania or from Serbia. Members of the active labor force are characterized by their low incomes, some of which is derived from the minimum wage - or the identical wages of "public workers" that is equivalent to 52-60,000 Hungarian Forint (HUF) per person per month (approx. 168-192 EUR) -, while supplementary incomes, also roughly equivalent to the previous sum, are derived from agriculture (animal breeding and small-scale vegetable growing). This has resulted in a significant decline in relative social status and position, as well as increasing insecurity in the domains of income and employment. An 
important component of discontent is the nostalgia for state-socialism that is mainly shared by the older generation.

The local government is currently the major employer in the village because, according to current Hungarian regulations, unemployment benefit may only be paid to those who are included in the public work programs that are funded by the state but managed and by local governments (Szőke 2015). The effectiveness of the public work system of the Orbán regime is highly contested by liberal economists, although some anthropologists and sociologists acknowledge that participation in public work supports the recognition and self-esteem of some of the poor (Hann 2016). Nevertheless, everybody agrees that the system increases the exposure of the poor to local power holders. This is clearly the case in Ásotthalom, where the mayor's office disposes of about one hundred employees, including the well-known former leader of an opposition party. A similar situation exists with local civil society. Besides the small number of people active in the Catholic Church, only those ethno-traditionalist groups are visible in the local public that have a close relationship with the countrywide organizations of the radicalright scene, again under the control of László Toroczkai.

Based on fieldwork in a nearby settlement (Tázlár), in a recent article Chris Hann used the metaphor "overheated underdogs" (Hann 2016) to describe the social groups that have been plunged into a desperate situation by 'post socialist semi-peripheral capitalism in rural Hungary.' According to Hann, and in consonance with an earlier analysis of the Hungarian farright (Feischmidt and Szombati 2017), social anxiety and disappointment is a major explanation of sympathy for any sort of politics that operate using Euroscepticism, nationalism, and the treatment of foreigners as scapegoats. Similarly, Cathrine Thorleifsson (2017) also found that a precarious labor market is the major factor driving anti-migration sentiment in Hungary. On a larger scale, Melegh (2018) emphasizes the effects of increasing economic inequalities globally and within the EU, thereby producing "positional insecurity" in Hungary 
that guarantees the success of a politics of fear because it promises to strengthen the relative position of the country.

\section{From precarious solidarity to fears captured by the far-right}

The current case study validates the aforementioned structural explanations and completes them with a thick description of how the social and economic insecurity of people living in the Hungarian border area were captured by the far-right ${ }^{9}$ both before and especially during the socalled refugee crisis. In the analysis of the local public I emphasize the disappearance of alternative actors to those of the far-right, a lack of trust in other public actors, as well as the low level of social cohesion and inclusion. I document how the power of the far-right has been extended by their monopoly on the "refugee crisis" and through their creation of a hegemonic discourse. How this has affected everyday perceptions of people on the move, and how the reactions of the locals have changed over time are the subjects of this section.

'When there were fewer [refugees] coming, people felt sorry for them and helped them out as much as they could. But as the crowd got larger and [the locals] got weary of them, after a while they [the refugees] become more and more undesirable' - my host, a woman in my age, told me on a late August day in 2015 in Ásotthalom. Her explanation for the initial compassion was that during the first wave - which residents identify with the winter and spring of 2015 - a smaller number of people arrived, many of them 'well-dressed men,' 'presumably educated,' and largely hidden from the public eye. In popular perception, the second wave was different, since by then it mainly involved the arrival of families, including many women and children. A willingness to help justified by empathy and civic responsibility manifested itself most intensively during this phase, which may be understood in terms of performative citizenship (Isin 2017). 
A local teacher described this period with unmistakable compassion in her voice: ' $I$ stopped [on my way] because it was so heart-breaking to see those people sitting there, crumbling under the freezing cold, and they just stayed there. I then discussed [the situation] with my colleagues, whether maybe we should bring them tea, and we should find out what else to do, that something must be done because this was frightening. Our doctor told us that he was called out to see a baby who was practically half-frozen. ... It was also said that one person brought along five others who were mentally ill because they hoped to get that status also for themselves, and so on. Apparently they carried everyone they could with them.'

A young man related with a sense of curiosity about the summer of 2015 how 'the whole world passed through the village.' Due to this phenomenon, in his own words, he is now able to 'orient himself much better in world politics.' He has worked as a citizen (nonprofessional) soldier for three years during which time he has also learnt English and partially also Serbian. Refugees regularly passed through his family's garden, but apart from picking a few peaches they did not cause any damage. Family members were not afraid of them; they even took pity on them and willingly gave them all that they could. The young citizen soldier and the members of his family emphasized their good relations with the foreigners, and the normality of their everyday encounters. 'I palled up with some of them, so to say ... we were talking, and it was all fine. He told me about his plan to move to Germany and that he wanted to work. Once we discussed the whole football World Cup with Kosovars, so it was something mutual.

The local catholic priest defined his own position as an ambivalent one, which was reflected in his preaching, which I attended, and also confirmed in our discussions. The essential point of this ambivalence as he defined it was the idea that if individuals listen to their hearts or minds, or make judgments as Christians or as politicians, they will come to different conclusions regarding the international migration wave that reached Hungary: 
People are concerned here ... While we are wasting [resources] on welfare states, other countries are starving. It is understandable that if they cannot conquer us with weapons, they will do so without them. ... If we listen to our hearts ... we should turn affectionately to the poor families with many children. In other people we can see Jesus, who identified himself with us, human beings, so we need to help, since God entrusted us to each other ... [However] If we listen to our minds, it is the duty of the Hungarian government to defend our nation.

The catholic priest resolved the dilemma for himself by helping refugees in the village personally but not asking others to do the same. The parish was open to refugees for a while and the church served as temporary accommodation for many families. Some of the guests were Christians, and according to the priest a few were even carrying the Bible in Arabic in their backpacks. Although locals usually described themselves as 'churchgoers and conservative' people, they did not actively host the refugees and help maintain the parish. The priest himself firstly became a hesitant but later a committed supporter of the mayor, and now supports him in relation to local politics first of all, but also concerning his far-right political ambitions at the national and international level too.

In August of 2015, when most people were arriving, the focus of perceptions shifted, as one of my interlocutors formulated '...when they started to come excessively, by the hundreds, those 13-14 year-old striplings in gangs, we just sensed that this was a flood.' The shift in perceptions can be associated as much with the transformation of framing. The effects of media accounts and local political communication were powerful enough to rearrange and supersede previous feelings of compassion and dispersed acts of solidarity. In September 2015, immediately after the border fence between Hungary and Serbia was built and the settlement ceased to be directly affected, local residents were claiming that they had had no personal contact with the people who had passed through the village and the area. To my question 'Were there any instances when you talked to anyone?' the most common response was something 
like this: 'I don't really know about such things, but perhaps people won't even talk about them. Once I was accosted by a man, but I didn't understand anything, so I just moved on.'

The local government prohibited personal contact with refugees. Moreover, retribution was taken against those who offered help. As one of my informants told me, albeit with some empathy: 'A schoolteacher was coming ... by car and she took pity on a woman with two children, so she picked them up in her car. A policeman charged her with human trafficking; the court case is still pending. What she did, she did humanely, without accepting any money for it. Then what about the buses that transported them? Was that also human trafficking?'

A couple of teachers at the local school were known to help refugees with food, water, or by giving them rides to the big city nearby from where they could continue their way by train. They initially had the silent support of the school management, which had once also helped distribute a big donation from abroad among refugee children and the children of poorer families in the village. Nevertheless, the school director was terrified by the thought that the mayor might withdraw his support for the basic activities of the school, which situation could have made the institution unsustainable. The director thereupon forbade any activity that involved supporting the refugees among the teachers, and also stopped talking with me about the topic. Nevertheless, some teachers continued their activities in the nearby city of Szeged where a group of around 150 volunteers helped the refugees during the summer of 2015 (Cantat 2020; Feischmidt and Zakariás 2019).

The retribution and stigmatization of altruistic supporters had the desired effect, but trafficking continued on a large scale. During my fieldwork I saw numerous cars waiting at the collecting point located in the vicinity of the settlement, and even in the village centre. There was a rumor about "Gypsy traffickers" from other settlements who said to be were regular transporters of refugees. It is noteworthy that in the Serbian village across the border, residents spoke about the transportation of refugees as a legitimate issue, partly as a service - in other 
words, a business - and partly as a form of voluntary assistance that took various forms, from casual transportation to taxi-like operations. The "Gypsization" of transporting the refugees across the border from Serbia to Hungary was thus already part of the process of delegitimization.

At a certain point, the initial diversity of perceptions and discourses completely disappeared. Narratives started to become increasingly homogeneous. Accordingly, highly selective observations came to fill out discursive frames: dominant themes included dirt, sanitary hazards, and the damage that had been caused.

Someone's electric fence was broken, ... And besides this, the heaps of garbage they left behind... It's a huge problem, not to mention the risk of infection, the diapers thrown away at the side of the road. Perhaps 40-50 percent of the people here live in homesteads and they don't dare to go out into their yards. At night, people are knocking on their doors. The sense of security ... Ásotthalom was a safe place.

As communication and personal interaction became increasingly rare, the sentiments that villagers reported concerning foreigners increasingly included feelings of disgust, anger, and irritation. Dehumanization seemed to be the end result. Revulsion was further deepened by envy and suspicion: 'How come people in need of help are able to run around with expensive smartphones, clothes and shoes?' The increase in anger never led to physical assault, but aggression was expressed in verbal forms, as the following man reports: 'Some were yelling from twenty meters 'why don't you throw bombs at them [the immigrants]?' and 'why don't you shoot them down?"'

On other occasions, fear was explained by a lack of knowledge and information about the arrivals, who were criminalized similarly to previously existing categories of racialized Others, primarily the Roma:

So many young men ... who knows what kind of skills they have with weapons or stabbing ... we are afraid, yes we are afraid. Now, if they are allowed to enter schools among 
Hungarian children, what will they take in there ... I'm afraid of this, or that I'll be walking in the street and then, if they don't like my look, they will attack me... Violence has occurred elsewhere.

The analysis of public discourse and private talk led us to the conclusion that the hegemony of fear developed gradually, mainly driven by the media and political actors. As has been shown, the perception of migrants as a threat was due to the invention of far-right political actors for whom the border village, Ásotthalom, became a scene for enacting the protection of the natives and exclusion of migrants in various ways. The policing of the border and the spectacle of threats delegitimized the narrative of compassion and the local initiatives of solidarity. Those once supportive of the refugees became silent, or sometimes even supporters of the securitizing discourses. Locals' own memories of flight which formerly aroused empathy - involving the villagers on the Serbian side of the border (Szerbhorvath 2016) and other border villages on the Balkan route -, were also silenced.

\section{Conclusion}

This paper commenced with a description of the everyday discourses encountered in the Hungarian border village of Ásotthalom that started with reflection about the various ways that migrants in transit on the Balkan route were perceived. Following this approach, the paper documented the transformation of the variety of discourses, which moved from mistrust through indifference to empathy to an emphasis on the fears and the insecurity of the village; a discourse dominated by stories and images fixated on threatening migrants. In the meantime, through the increase in media coverage, the border village became the scene of a spectacle of "migration crisis" and "border control." In the construction of the border spectacle the major players were the Hungarian far-right and the mayor of Ásotthalom, but further political and media actors contributed to it on the local, national, and transnational level. 
As the literature claims, this paper confirms that the far-right may increase its power by building on fears and showing its capacity to increase security by controlling national borders and by strengthening the perceptual boundaries between natives (perceived as people from Ásotthalom, Hungarians, or white, Christian Europeans) and people on the move (perceived as racialized or dehumanized Others). Migrants have been the subject of racist representations and dehumanization connected to othering that has recently affected other social groups in the country, most particularly Roma (Cantat and Rajaram 2018; Feischmidt and Hervik 2016), and Muslims (Vidra 2017).

The paper also provides evidence for the synergy between the authoritarian government which makes enemies and security the main issue of governance and small, far-right initiatives. Our analysis was focused on local developments in the border village of Ásotthalom where we found that the far-right successfully maneuvered itself into dominant position by creating spectacles which came to be represented as actions of collective defense and the legitimization of surveillance, as well as by connecting the situation to the securitizing state. The interconnection of media and politics has also been proven. While protection and border control are presently the focus of governance, the media imaginary is focused on threats and follows the logic of dehumanizing migrants and abnormalizing both migration and solidarity with migrants.

Finally, the investigation of the socioeconomic background of the current processes has shown the magnitude of social anxiety fostered by relative deprivation and the current peripheral position of the village both within the country and even more in terms of the European Union. The case of Ásotthalom is an example of the silent revolt of the people of the European peripheries against immigrants, and even more, against the transnational forms of solidarity promoted by politicians and civic activists, represented for the villagers by the liberal elite of Europe. The immediate reactions of locals initially included compassion and civic 
responsibility. Nevertheless, such empathetic voices and solidarity action were not strong enough to counter the political actors who became interested in turning up the volume of fear. The case also shows that solidarity cannot become consolidated and institutionalized in an environment in which civil society is weak, the general level of trust is low, and the local public may be disposed of by political powers who manipulate existing social anxieties.

\section{Acknowledgments}

The empirical research for this paper was supported by the Incubator Program of the Centre for Social Sciences at the Hungarian Academy of Sciences. Previous versions of this paper have been presented at the biannual conference of the European Association of Social Anthropologists in 2016 in Milan, at the American Anthropological Association Annual Meeting in 2018 in Washington, and at various other conferences and workshops in Hungary and Germany. A first version of the paper was published in Hungarian in 2016 and in German in 2017. The manuscript was completed in 2018 when the author was a guest researcher at the Max Planck Institute for Social Anthropology in Halle. I would hereby like to say thank you for the material and intellectual support to all the mentioned persons and institutions. Special thanks are also due to the following individuals for their critical reading and comments on previous versions of this paper: Irene Götz, Chris Hann, Peter Hervik, Attila Melegh, Vlad Naomescu, Szabolcs Pogonyi, Gergely Pulay, Prem Kumar Rajaram, Marketa Spriritova, Helen Schwenken, Helge Schwiertz, György Szerbhorvát Mónika Váradi and Ildikó Zakariás.

\section{References}

Altheide, D. 2002. Creating Fear: News and the Construction of Crisis. Hawthorne, NY: Aldine de Gruyter.

Bartha, E. 2011. "It Can't Make Me Happy that Audi is Prospering': Working Class Nationalism in Hungary after 1989." In Headlines of Nation, Subtext of Class: Working Class Populism and the Returned of the Repressed in a Neoliberal Europe, edited by Don Kalb, and Gabor Halmai, 92-112. New York. Oxford: Berghahn.

Bauböck, R., and P. Scholten. 2016. "Solidarity in diverse societies: beyond neoliberal multiculturalism and welfare chauvinism. Introduction. Coping with 'the progressive's 
dilemma'; nationhood, immigration and the welfare state." Comparative Migration Studies 4(4). https://doi.org/10.1186/s40878-016-0025-Z

Bernáth, G., and V. Messing. 2016. Infiltration of political meaning production: security threat or humanitarian crisis? The coverage of the refugee 'crisis' in the Austrian and Hungarian media in early autumn 2015. Research Report. CEU, Budapest. https://www.ceu.edu/sites/default/files/attachment/article/17101/infiltrationofpolitical meaningfinalizedweb.pdf

Buchowski, M. 2017. “A New Tide of Racism, Xenophobia, and Islamophobia in Europe: Polish Anthropologists Swim Against the Current.” American Anthropologist 119(3): 519-52.

Buzan, B., O. Wæver, and J. de Wilde. 1998. Security. A new Framework for Analysis. Boulder (CO): Lynne Rinner.

Cantat, C. and P. K. Rajaram. 2018. "The Politics of Refugee Crisis in Hungary: B/ordering the Nation and Its Others." In The Oxford Handbook of Migration Crises, edited by C. Menjívar, M. Ruiz, and I. Ness, 1-17. Oxford: Oxford University Press.

Cantat. C. 2020. "Governing Migrants and Refugees in Hungary: Politics of Spectacle, Negligence and Solidarity in a Securitizing State." In Politics of (Dis)Integration, edited by S. Hinger, and R. Schweitzer, 183-199. Cham: Springer.

De Genova, N. 2013. "Spectacles of Migrant Illegality: The Scene of Exclusion, the Obscene of Inclusion.” Ethnic and Racial Studies 36 (7): 1180-1198.

Fassin, D. 2011. "Policing Borders, Producing Boundaries. The Governmentality of Immigration in Dark Times.” Annual Review of Anthropology 40 (2): 213-226.

Feischmidt, M., and P. Hervik. "Mainstreaming the Extreme: Intersecting Challenges from the Far Right in Europe." Intersections. EEJSP 1 (1): 1-15.

Feischmidt, M. and K. Szombati. 2017. "Understanding the rise of the far right from a local perspective: Structural and cultural conditions of ethno-traditionalist inclusion and racial exclusion in rural Hungary." Identities. 24(3): 313-331. doi: 10.1080/1070289X.2016.1142445.

Feischmidt, M., and I. Zakariás. 2019. "Politics of Care and Compassion. Civic Help for Refugees and Its Political Implications in Hungary - a Mixed-Methods Approach.” In Refugee Protection and Civil Society in Europe, edited by M. Feischmidt, L. Pries, and C. Cantat, 59-99. Cham: Palgrave Macmillan. 
Hann, C. 2016. "Overheated Underdogs: Civilizational Analysis and Migration on the DanubeTisza Interfluve.” In: History and Anthropology 27(5): 602-616. doi:10.1080/0275 7206.2016.1219353.

Helms, E. 2016. "Men at the Borders: Gender, victimhood, and War in Europe's Refugee Crisis" http://www.focaalblog.com/2015/12/22/elissa-helms-men-at-the-bordersgender-victimhood-and-war-in-europes-refugee-crisis/

Huysman, J. 2006. The Politics of Insecurity. Fear, Migration and Asylum in the EU. London and New York: Routledge

Kalb, D. 2011. Introduction. Headlines of Nation, Subtexts of Class: Working-Class Populism and the Return of the Repressed in Neoliberal Europe. In Headlines of Nation, subtext of Class. Working Class Populism and the Returned of the Repressed in a Neoliberal Europe, edited by D. Kalb, and G. Halmai, 1-36. New York. Oxford: Berghahn.

Isin, E. 2017. "Performative Citizenship." In The Oxford Handbook of Citizenship, edited by A. Shachar, R. Bauböck, I. Bloemraad, and M. Viink, 500-523. Oxford: Oxford University Press.

Melegh A. 2018. "Counter Hegemony and the Rise of a New Historical Political Block.

Transform! Europe" https://www.transform-network.net/en/blog/article/counterhegemony-and-the-rise-of-a-new-historical-political-block/

Messing, V., and B. Ságvári. 2018. "Looking behind the Culture of Fear. Crossnational Analysis of Attitudes towards Migration.” Friedrich-Ebert-Stiftung Regional Project Flight, Migration, Integration in Europe. Budapest. http://library.fes.de/pdffiles/bueros/budapest/14181.pdf

Nagy, B., and Sonnevend P. 2018. „Das Asylrecht als Mittel der Isolation - Das Beispiel Ungarns“. In Asylrecht und Asylpolitik in der Europaischen Union. Eine deutschungarische Perspektive, edited by M. Anderheiden, H. Brzozka, U. Hufeld, and S. Kirste, 217-256. Baden-Baden: Nomos.

Oosterlynck, S., M. Loopmans, N. Schuermans, J. Vandenabeele, and S. Zemni. 2015. "Putting Flesh to the Bone: Looking for Solidarity in Diversity, Here and Now." Ethnic and Racial Studies (39)5: 764-782. doi: doi.org/10.1080/01419870.2015.1080380

Pasieka, A. 2017. "Taking Far Right Claims seriously and Literally: Anthropology and the Study of Right-Wing Radicalism." Slavic Review 76 (1), 19-29. https://doi.org/10.1017/slr.2017.154

Pries, L. 2019. "Introduction. Civil Society and Volunteering in the so-called Refugee Crisis of 2015 - Ambiguities and Structural Tension.” In Refugee Protection and Civil Society 
in Europe, edited by M. Feischmidt, L. Pries, and C. Cantat, 2-21. Cham: Palgrave Macmillan.

Rajaram, P. K. 2016. "Whose Migration Crisis?” Editorial Introduction. Intersections. EEJSP 2(4): 3-10 doi: https://doi.org/10.17356/ieejsp.v2i4.314.

Szalai, A., and G. Göbl. 2015. "Securitizing Migration in Contemporary Hungary." Working Paper. Budapest: CEU Center for EU Enlargement Studies.

Schwiertz, H., and Schwenken, H. 2020. "Introduction: Inclusive Solidarity and Citizenship along Migratory Routes in Europe and the Americas." Citizenship Studies [[SI]].

Szerbhorváth, Gy. 2016. "Refugees in the Village. The Role of Media Representation, the Local Memory and Social Relations." [In Hungarian.] Regio 4: 33-60.

Szőke, A. 2015. “A 'Road to Work'? The Reworking of Deservedness, Social Citizenship and Public Work Programs in Rural Hungary." Citizenship Studies 19(6-7): 734-750. https://doi.org/10.1080/13621025.2015.1053790

Steuter, E., and D. Wills. 2010. “"The vermin have struck again”: dehumanizing the enemy in post 9/11 media representations." Media, War \& Conflict 3 (2): 152-167.

Thorleifsson, C. 2017. "Disposable Strangers: Far-right Securitisation of Forced Migration in Hungary." Social Anthropology/Anthropologie Sociale 25(3): 318-334. doi: 10.1111/1469-8676.12420.

Vidra, Zs. 2017. “Counter-Islamophobia Kit: Dominant Islamophobic Narratives in Hungary.” Working Paper Series Centre for Policy Studies. Budapest: CEU. http://pdc.ceu.hu/archive/00007234/01/cps-working-paper-countering-islamophobiadominant-islamophobic-narratives-hungary-2017.pdf

Wodak, R. 2015. The Politics of Fear: What Right-Wing Populist Discourses Mean. Thousand Oaks USA: Sage. http://dx.doi.org/10.4135/9781446270073

\footnotetext{
${ }^{1}$ Source: Tárki Omnibusz 2014-2016.http://www.tarki.hu/hu/news/2016/kitekint/20160404_idegen.html
} 
${ }^{2}$ The referendum question was the following: "Do you want to allow the European Union to mandate the resettlement of non-Hungarian citizens to Hungary without the approval of the National Assembly?" Source: https://en.wikipedia.org/wiki/Hungarian_migrant_quota_referendum,_2016

${ }^{3}$ http://alfahir.hu/szerte_europabol_koszonetet_mondanak_toroczkainak

4 "I would send all illegal migrants to the US - Hungarian Town Mayor" http://sputniknews.com/europe/20151012/1028404649/Ásotthalom-mayor-interview.html\#ixzz471oqyFLu 5 http://www.dailymail.co.uk/news/article-3240272/Hungarian-mayor-mocked-action-movie-video-warningmigrants-not-enter-town-including-choreographed-chase-horseback.html

6 "The fence had sealed Hungary off, and that made László Toroczkai - the 37-year-old mayor of Ásotthalom, a Hungarian farming town on the Serbian border, and a rising ultranationalist star of far-right European politics - very happy." http://www.nytimes.com/2015/12/20/magazine/has-europe-reached-the-breakingpoint.html? $\mathrm{r}=0$

${ }^{7}$ The title of the program: Migrants and Refugees (HBO). Source:

https://www.youtube.com/watch?v=umqvYhb3wf4

${ }^{8}$ About the relations between the Polish and the Hungarian far-right, see Pasieka 2017.

${ }^{9}$ For similar argumentation, see: Kalb and Halmai 2011, Bartha 2011.

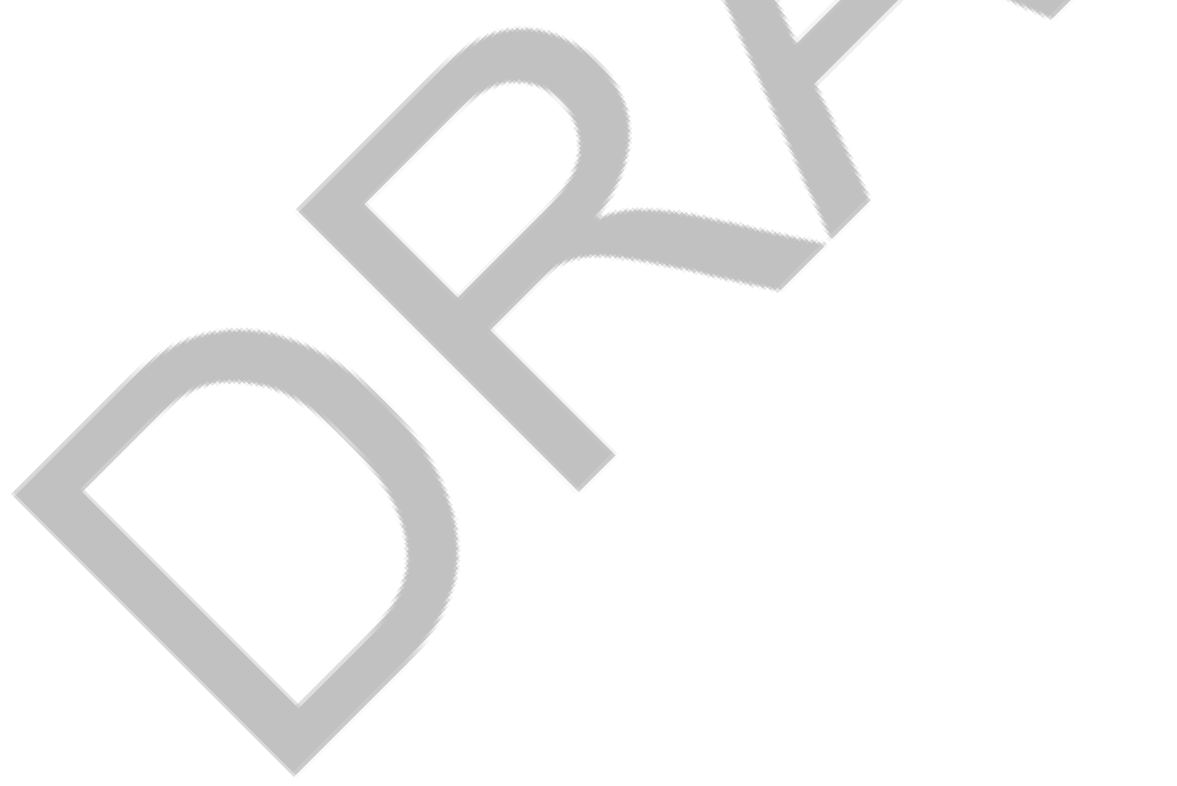

